\section{SOI: $1.1 / \mathrm{TAS} \quad$ DOI: $10.15863 / \mathrm{TAS}$ \\ International Scientific Journal Theoretical \& Applied Science}

p-ISSN: 2308-4944 (print) e-ISSN: 2409-0085 (online)

Year: $2015 \quad$ Issue: 09 Volume: 29

Published: $30.09 .2015 \quad \underline{\text { http://T-Science.org }}$
Oleg Borisovich Koshlaty

$\mathrm{PhD}$, Associate Professor

Poltava National Technical Yuri Kondratyuk University,

Ukraine

Alla Nikolaevna Kariuk

PhD, Associate Professor

Poltava National Technical Yuri Kondratyuk University,

Ukraine

kariuk@mail.ru

Roman Anatol'yevich Mischenko

$\mathrm{PhD}$, Associate Professor

Poltava National Technical Yuri Kondratyuk University,

Ukraine

\title{
THE DEVELOPMENT AND PROSPECTS ANALYSIS OF BUILDINGS THERMAL PROTECTION STANDARDIZATION IN UKRAINE
}

\author{
Abstract: In recent years in Ukraine, as in other countries, thermal buildings regulations have significantly \\ increased. The energy-saving policy should be further continued together with implementing energy-efficient \\ buildings. \\ Key words: thermal resistance, thermal protection, energy saving, rationing. \\ Language: English \\ Citation: Koshlatyi OB, Kariuk AM, Mischenko RA (2015) THE DEVELOPMENT AND PROSPECTS \\ ANALYSIS OF BUILDINGS THERMAL PROTECTION STANDARDIZATION IN UKRAINE. ISJ Theoretical \\ \& Applied Science 09 (29): 21-23.
}

Soi: http://s-o-i.org/1.1/TAS-09-29-5 Doi: crossef http://dx.doi.org/10.15863/TAS.2015.09.29.5

For almost half a century, there have been significant changes in the thermotechnical qualities standardization of general purpose building envelopes. First of all, the importance of the normative (economically viable), and, respectively, the actual thermal resistance of external walling has significantly increased. However, even nowadays, the total heat loss through the buildings' envelopes makes in Ukraine about $350 \mathrm{mln} \mathrm{GJ/year,} \mathrm{to}$ compensate which it is required to burn about 14 billion $\mathrm{m}^{3}$ of gas. Through walls these losses reach $170 \mathrm{mln}$ GJ/year of heat, to receive which it is required to burn almost 6.5 billion $\mathrm{m}^{3}$ of gas, and through windows it makes more than $155 \mathrm{mln}$ GJ/year (about 6 billion $\mathrm{m}^{3}$ of gas) [1]. The heat energy consumption for heating multicompartment buildings ranges from 350 to $600 \mathrm{kWh} / \mathrm{m}^{2}$ per year, while in Sweden and Finland it only makes 135-150 $\mathrm{kWh} / \mathrm{m}^{2}$, i.e. 3-4 times less [2]. The thermal protection standards of civil buildings, which were in force in Ukraine in the period from 1994 to 1997 , were still lagging behind the regulations in a number of countries, though they increased the required thermal resistance of building envelopes by 2-2.5 times and more. If compared with such countries as Germany, Denmark, Great Britain, our standards yielded insignificantly, however, they were lagging behind the norms of Sweden more than twice. The specific energy consumption in residential buildings of Sweden is the lowest among foreign countries. Therefore, an energy-efficient house in the country is heated on a cold winter day with an armful of firewood, or with 2 liter of oil fuel to obtain the temperature of $20^{\circ} \mathrm{C}$ in each room. The thermal resistance of the civil buildings walls in Sweden reaches $8.0 \mathrm{~m}^{2} \times \mathrm{K} / \mathrm{W}$. It should be noted, that the heat insulation effect-cost ratio has the most optimum value at the increase of the walls opaque portions thermal resistance from 0.8 to $2.8 \mathrm{~m}^{2} \mathrm{xK} / \mathrm{W}$ and for window frame structures it ranges from 0.4 to 0.8 $\mathrm{m}^{2} \times \mathrm{K} / \mathrm{W}$. The provided, according to DBN (Construction Rules and Regulations) B.2.6-31:2006 "Thermal Buildings Insulation" [3], in 2007, raising the requirements to heat-transfer resistance for opaque areas (walls) up to $2.8 \mathrm{~m}^{2} \times \mathrm{K} / \mathrm{W}$ gives significantly higher (almost three times) overall effect, than that obtained with a gradual increase of this index to $2.5 \mathrm{~m}^{2} \times \mathrm{K} / \mathrm{W}$. Further increase of the opaque walls heat-transfer resistance exceeding 3.5 $\mathrm{m}^{2} \times \mathrm{K} / \mathrm{W}$ does not have so significant impact on the total economic effect at a fixed energy products price $[4,5]$.

The data obtained by MNIITEP (Moscow) confirm, that further raising the walls thermal resistance when $\mathrm{R}_{0}>3,5 \mathrm{~m}^{2} \times \mathrm{K} / \mathrm{W}$ does not give such an observable effect in energy consumption, as at the previous stages, when this index was reduced by $25 \%$. If we continue raising the heat-transfer resistance from 3 to $5 \mathrm{~m}^{2} \times \mathrm{K} / \mathrm{W}$, the power consumption will be only reduced by $3-5 \%$. However, in recent years, Russia and the Baltic 
countries (Lithuania, Latvia, Estonia) have significantly raised the buildings thermal protection standards and the value of heat-transfer resistance is much higher than $3.0 \mathrm{~m}^{2} \times \mathrm{K} / \mathrm{W}$. For example, in the Moscow experimental residential area of Kurkino, the so-called "warm" houses were built, where the specific heat consumption for heating and hot water is by 3-3.5 times lower than in houses that meet the requirements of the heating- performance standards [6] of that time. All exterior envelopes have increased heat-transfer resistance: the walls - 6.5, coating - 8.6, basement floor - 9, windows - 1 $\mathrm{m}^{2} \times \mathrm{K} / \mathrm{W}$ [7]. Exterior walls make a layered selfsupporting structure of the "ventilated cladding" type, where a half-brick walling performs the function of a screen, thus permitting to fulfill the investor's requirements of the brick house simulation.

Despite the fact that formerly DBN B.2.631:2006 [3] standard was sufficiently advanced, in recent years, it is no longer economically viable.
Approved late in 2012, Change No. 1 to these regulations has significantly raised the requirements as to the minimum values of walling structures heattransfer resistance $\mathrm{R}_{\mathrm{q}}{ }^{\mathrm{min}}$. For the $1 \mathrm{st}$ temperature zone, which area has significantly increased (including 20 regions out of 25), this index has risen from 2.8 to $3.3 \mathrm{~m}^{2} \times \mathrm{K} / \mathrm{W}$ for walls. Therefore, the effective thickness of walling made of different materials is significantly increasing. The dynamic pattern of the specified heat-transfer resistance and the effective thickness of the walls made of different materials are shown in Fig. 1. However, taking into consideration the Ecofys studies, there are recommendations on further raising the standard $\mathrm{R}_{\mathrm{q}}{ }^{\mathrm{min}}$ values: for walls - up to 5.0; for coatings - 5.9; for ground floor - $3.9 \mathrm{~m}^{2} \times \mathrm{K} / \mathrm{W}$ [4], which considerably exceeds the standard values of thermal insulation adopted both in Ukraine and in other countries with similar climate.

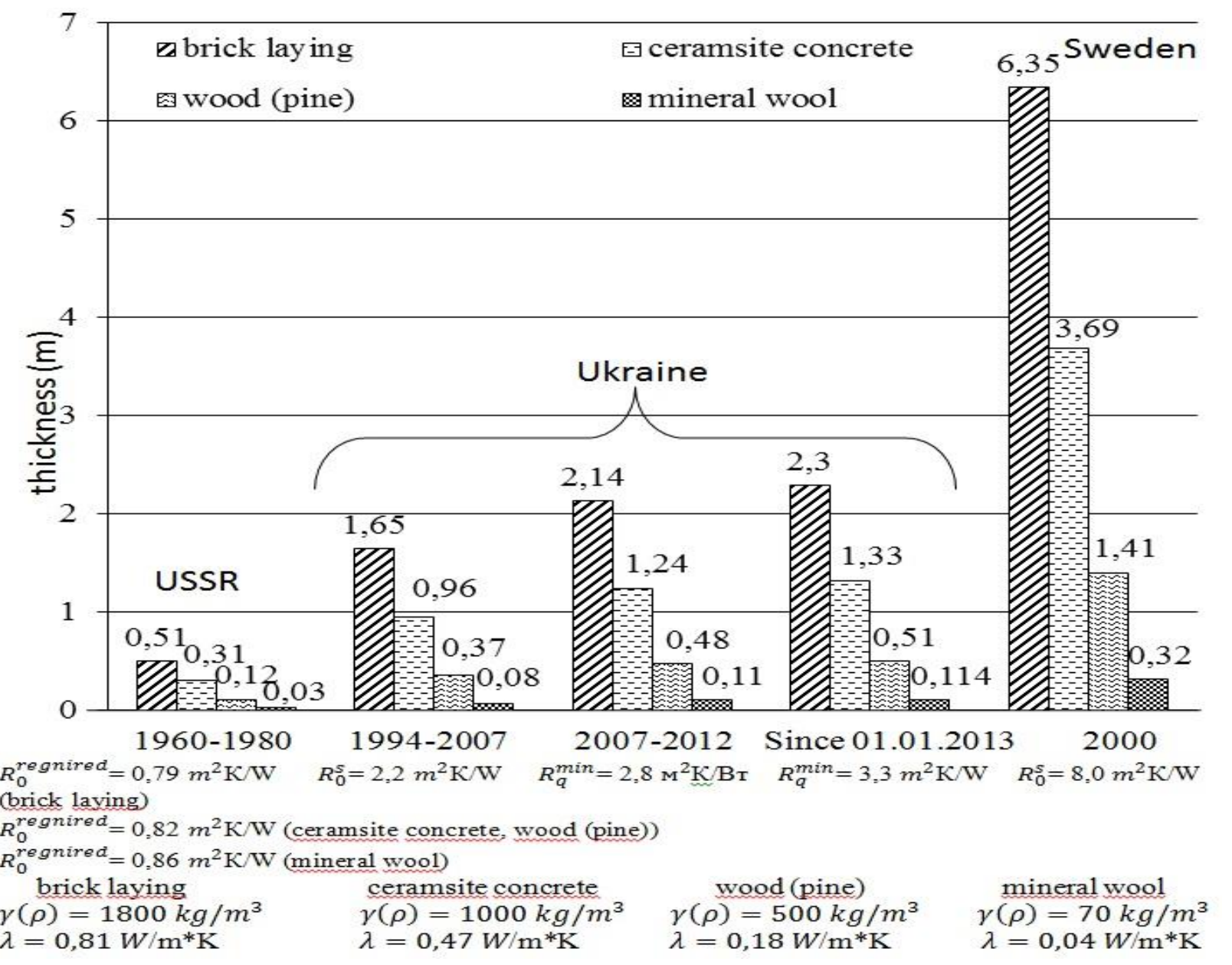

Figure 1 - Diagram of the outer walls expected thickness for civic buildings according to thermal protection standards for different periods. 
The thermotechnical calculations updating also helps to solve the problem of energy saving, the most volatile and the least studied parameter being the atmospheric air temperature. The results of the studies $[9,10]$ permitted to calculate the values of the temperature, taking into account the expected working life of the building and the thermal inertia value of the building's envelopes.

Thus, the analysis of the national and world experience testifies to the necessity of further energy saving policy, implementation of energy-efficient buildings with consideration of the energy market situation, using the advanced countries' achievements, avoiding their mistakes in this respect. High level of the buildings thermal protection and the use of efficient, high-quality thermal insulation will also improve the ecological situation and reduce environmental pollution, though, of course, it will require additional simultaneous inputs for manufacturing and using up-to-date, efficient thermal insulation materials. The payback time of these measures will depend on the ratio of capital and operating costs (of energy products), but we obviously have no alternative to the above measures.

\section{References:}

1. Beshynska OV, Ratushniak OH (2006) Teplotekhnichna otsinka yakosti ohorodzhuvalnykh konstruktsii zhytlovykh ta hromadskykh budivel // zhurnal Asotsiatsii inzheneriv enerhoefektyvnykh tekhnolohii Ukrainy. - 2006. - №2. $\quad$ - pp.18-19.

2. Kurbatov VL (2004) Povyshenie effektyvnosty enerhosberezhenyia sovershenstvovanyem teplozashchyty naruzhnykh sten zdanyi // Stroytelnye materyaly, oborudovanye, tekhnolohyy XXI veka. - 2004. - №3. - pp.4647.

3. (2006) DBN V.2.6-31:2006. Teplova izoliatsiia budivel. -Kiev, Minbud Ukrainy, 2006. -40 p.

4. (2003) SNyP 23-03-2003. Teplovaia zashchyta zdanyi. - Moscow, Hosstroi Rossyy, 2003. - 33 p.

5. Fareniuk HH (2008) Enerhetychna efektyvnist pidvyshchennia teplotekhnichnykh pokaznykiv osnovnykh elementiv teploizoliatsiinoi obolonky budynkiv // Budivnytstvo Ukrainy. 2008. - №8. - pp.12-14.

6. Fareniuk HH (2009) Osnovy zabezpechennia enerhoefektyvnosti budynkiv ta teplovoi nadiinosti ohorodzhuvalnykh konstruktsii /
H.H. Fareniuk. - K.: Hama-Prynt, 2009. - 216 p.

7. Beloded SD, Spyvak AN (2003) «Teplye» doma $\mathrm{v}$ eksperymentalnom raione Kurkyno // Promyshlennoe y hrazhdanskoe stroytelstvo. 2003. №7. - pp. 18- 20.

8. Serheichuk OV, Dyb MV (2013) O perspektyve dalneisheho uvelychenyia teployzoliatsyy naruzhnykh ohrazhdaiushchykh konstruktsyi v Ukrayne // Spetsvypusk № 4 naukovoho zbirnyka „Enerhoefektyvnist $\mathrm{u}$ budivnytstvi ta arkhitekturi" (za materialamy 3-yi Mizhnarodnoi naukovo-praktychnoi konferentsii „Enerhointehratsiia - 2013”, 15-17 travnia 2013). -K. - pp. 253-258.

9. Pashynskyi VA, Pushkar NV, Kariuk AM (2013) Temperaturni vplyvy na ohorodzhuvalni konstruktsii budivel (monohrafiia) / / - Odesa, 2012. $-180 \mathrm{p}$.

10. (2010) DSTU-N B V.1.1 - 27:2010. Zakhyst vid nebezpechnykh heolohichnykh protsesiv, shkidlyvykh ekspluatatsiinykh vplyviv, vid pozhezhi. Budivelna klimatolohiia. - K., 2010. $-101 \mathrm{p}$. 